\title{
ЧИННИКИ, ЯКІ ВПЛИВАЮТЬ НА СМЕРТНІСТЬ ХВОРИХ НА СИСТЕМНИЙ ЧЕРВОНИЙ ВОВЧАК (ПРОСПЕКТИВНЕ ДОСЛІДЖЕННЯ)
}

\author{
Уляна Абрагамович, к.мед.н., дочент кафедри внутрішньої медищини №2, Львівський \\ начіональний медичний університет імені Данила Галищького, м. Львів, Украӥна, \\ http://orcid.org/0000-0003-4762-3857 \\ Орест Абрагамович, д.мед.н., професор, завідувач кафедри внутрішньої медицини №1, \\ Львівський національний медичний університет імені Данила Галицького, м. Львів, Украйна, \\ http://orcid.org/0000-0001-6862-6809
}

Роман Дутка, д.мед.н., професор, завідувач кафедри пропедевтики внутрішньої медицини №1, Львівський національний медичний університет імені Данила Галицького, м. Львів, Украйна, http://orcid.org/0000-0002-2130-9811

Марта Фармага, к.мед.н., асистент кафедри внутрішньої медичини №1, Львівський начіональний медичний університет імені Данила Галицького, м. Львів, Украйна, http://orcid.org/0000-0003-1298-4644

Соломія Гута, асистент кафедри внутрішньої медицини №1, Львівський начіональний медичний університет імені Данила Галицького, м. Львів, Україна,

http://orcid.org/0000-0002-7943-0139

DOI: https://doi.org/10.31435/rsglobal_wos/30062020/7127

\section{ARTICLE INFO}

Received: 19 April 2020

Accepted: 13 June 2020

Published: 30 June 2020

\section{KEYWORDS}

systemic lupus erythematosus, mortality, prognosis.

\begin{abstract}
Introduction. Systemic lupus erythematosus is accompanied by lesions in vital organs and systems and significantly reduces the life expectancy of patients. Attempts have been made to identify the main factors that worsen the prognosis of patients and increase the risk of mortality. The obtained information has often been fragmentary, taking account of only a few factors, and sometimes contradictory.

Objective. To identify factors that affect the mortality of patients with systemic lupus erythematosus.

Materials and methods. 294 patients after stratification by the presence of systemic lupus erythematosus were randomly enrolled in a prospective study. The study was conducted in two phases. The first phase consisted of three consecutive steps. At the first step we analyzed passport data, at the second step - the presence of ACR criteria, and at the third step - the presence of pathogenetically associated with SLE organ lesions. In general, the first phase dealt with the analysis of factors that determine the survival of patients with SLE. The purpose of the second phase was to identify constellations of manifestations that most significantly determine the risk of death.

Results. Factors that increase the mortality of patients with SLE are male sex, age (under 42.5 years), proteinuria and cylindruria, seizures, lymphopenia, lupus anticoagulant antibodies, as well as the presence of myocarditis, pneumonitis, autoimmune hepatitis, aseptic necrosis, chronic caries. However, the combination of male sex, overweight (over $92.5 \mathrm{~kg}$ ) and autoimmune hepatitis plays the most important role.
\end{abstract}

Citation: U. Abrahamovych, O. Abrahamovych, R. Dutka, M. Farmaha, S. Guta. (2020) Factors Affecting Mortality of Patients with Systemic Lupus Erythematosus (Prospective Study). International Academy Journal Web of Scholar. 6(48). doi: 10.31435/rsglobal_wos/30062020/7127

Copyright: (C) 2020 U. Abrahamovych, O. Abrahamovych, R. Dutka, M. Farmaha, S. Guta. This is an open-access article distributed under the terms of the Creative Commons Attribution License (CC BY). The use, distribution or reproduction in other forums is permitted, provided the original author(s) or licensor are credited and that the original publication in this journal is cited, in accordance with accepted academic practice. No use, distribution or reproduction is permitted which does not comply with these terms. 
Вступ. Системний червоний вовчак (СЧВ) супроводжується ураженням життєво важливих органів та систем і суттєво знижує тривалість життя хворих [1, 4]. Відомо, що у перші десять років зазвичай помирають 10,0 \% пацієнтів з СЧВ, за 20 років - 13,0 \% пацієнтів [8]. Прогноз тривалості життя хворих на СЧВ залежить від характеру перебігу хвороби, статі і віку пацієнта, ураження тих чи інших органів і систем, але яких саме - досі не виявлено. В останні роки були спроби виокремити основні чинники, які погіршують прогноз хворих та збільшують ризик смерті, однак отримана інформація часто була фрагментарною, результатом аналізу лише поодиноких чинників, а деколи суперечливою $[4,5,7]$, що і визначило потребу цього дослідження.

Мета дослідження. Виявити чинники, які впливають на смертність хворих на системний червоний вовчак.

Матеріали й методи дослідження. Після отримання письмової згоди на проведення комплексного обстеження, згідно 3 принципами Гельсінкської декларації прав людини, Конвенції Ради Європи про права людини і біомедицину, відповідними законами України та міжнародними актами, у рандомізований спосіб із попередньою стратифікацією за наявністю СЧВ (Наказ Міністерства охорони здоров’я України № 676 від 12.10.2006р. «Про затвердження протоколів надання медичної допомоги за спеціальністю «Ревматологія»»» із змінами, внесеними згідно з Наказами № 263 від 11.04.2014 р., № 762 від 20.11.2015 р., рекомендації Європейської ліги проти ревматизму, 2010 р., Американської колегії ревматологів (American College of Rheumatology - ACR), 2010 p., 2012 p.) у проспективне дослідження залучено 294 хворих (262 жінок $(89,12 \%)$ і 32 чоловіків $(10,88$ \%) у віці від 18 до 74 років, які в 2010-2018 pp. лікувалися у ревматологічному відділі Комунального некомерційного підприємства Львівської обласної ради «Львівська обласна клінічна лікарня», що є клінічною базою кафедр внутрішньої медицини №1 та №2 Львівського національного медичного університету імені Данила Галицького.

Для діагностики патогенетично асоційованих 3 СЧВ уражень органів i систем обстеження хворих проводили згідно наказів Міністерства охорони здоров’я України № 676 від 12.10.2006 p. «Про затвердження протоколів надання медичної допомоги за спеціальністю «Ревматологія»»» із змінами, внесеними згідно з наказами № 263 від 11.04.2014 р., № 762 від 20.11.2015 р. та 3 урахуванням критеріїв Американського коледжу ревматології (American College of Rheumatology - ACR); № 436 від 03.07.2006 p. «Про затвердження протоколів надання медичної допомоги за спеціальністю «Кардіологія»»" із змінами, внесеними згідно з наказам № 384 від 24.05.2012 р., № 455 від 02.07.2014 р.; № 128 від 19.03.2007 р. «Про затвердження клінічних протоколів надання медичної допомоги за спеціальністю «Пульмонологія»»" із змінами і доповненнями, внесеними наказами № 555 від 27.06.2013 р., № 868 від 8.10.2013 р.; № 271 від 13.06.2005 «Про затвердження протоколів надання медичної допомоги за спеціальністю «Гастроентерологія»») із змінами, внесеними згідно 3 наказами № 943 від 31.10.2013 р., № 613 від 03.09.2014 р., № 638 від 10.09.2014 р.; № 593 від 2.12.2004 р. «Про затвердження протоколів надання медичної допомоги за спеціальністю «Нефрологія» із змінами і доповненнями, внесеними наказом № 384 від 24.05.2012 р.;№ 356 від 22.05.2009 р. «Про затвердження протоколів надання медичної допомоги за спеціальністю «Ендокринологія»»» із змінами і доповненнями, внесеними наказами № 574 від 05.08.2009 р., № 1118 від 21.12.2012 р.; № 487 від 17.08.2007 p. «Про затвердження клінічних протоколів надання медичної допомоги за спеціальністю «Неврологія»»» із змінами, внесеними згідно з наказами № 602 від 03.08.2012 р., № 275 від 17.04.2014 p.; № 117 від 15.03.2007 p. «Про затвердження протоколів надання медичної допомоги за спеціальністю «Офтальмологія»» із змінами, внесеними згідно з наказами № 827 від 08.12.2015 p., № 49 від 28.01.2016 р.; № 647 від 30.07.2010 р. «Про затвердження клінічних протоколів надання медичної допомоги хворим зі спеціальності «Гематологія»» із змінами, внесеними згідно з наказами № 72 від 30.01.2013 р., № 866 від 08.10.2013 р., № 433 від 26.06.2014 р., № 808 від 04.11.2014 p., № 710 від 02.11.2015 р., № 711 від 02.11.2015 р., № 797 від 29.07.2016 р., оцінюючи інформацію 3 паспорта, скарги хворих, анамнез хвороби та життя, отриману за допомогою комплексного об'єктивного огляду, результатами додаткових лабораторних та інструментальних обстежень, оглядів суміжних спеціалістів.

За хворими велося проспективне спостереження, починаючи від появи перших симптомів СЧВ до (щодо хворих на СЧВ, що померли) моменту їх смерті, або (щодо хворих на 
СЧВ, що живі) до січня 2020 року, тобто до моменту початку аналізу чинників, які впливають на летальність хворих на СЧВ.

Дослідження проводили у два етапи: перший етап, який складався з трьох послідовних кроків, де на першому кроиі ми аналізували інформацію $з$ паспорта хворих, на другому наявність критеріїв ACR, а на третьому - наявність патогенетично асоційованих із СЧВ уражень органів, присвячений аналізу тих виокремлених на кожному кроці чинників, які впливають на виживання хворих на СЧВ; другий етап присвячений виявленню констеляцій ознак, які найбільш вагомо впливають на ризик смерті.

Статистичний аналіз проводився за допомогою програмного продукту IBM SPSS Statistics. Аналіз виживання проводився на основі побудови кривих Е. Л. Каплана - П. Майєра, які відображають зміну кумулятивної емпіричної ймовірності виживання кожного року після появи перших симптомів. Для категорійних змінних було побудовано криву виживання для кожної категорії і проведено лог-ранк тест Н. Мантела - Д. Кокса для порівняння розподілу виживання для різних категорій. Достовірною різниця ймовірності виживання для різних категорій (для пацієнтів із наявністю чи відсутністю ознаки) вважається нами за рівня значущості $\chi 2$-критерію, меншому за 0,05 . Для чисельних ознак (змінних) було побудовано характеристичні ROC-криві для знаходження точки відсікання, тобто, граничної точки, за допомогою якої можна розбити чисельну змінну на дві категорії, в результаті чого отримували оптимальну комбінацію чутливості і специфічності. Оптимальною вважалася комбінація із максимальним значенням показника А. Н. Колмогорова - Н. В. Смирнова. Після цього чисельну змінну було розбито на дві категорії і продовжено аналіз, як для категорійної змінної.

Результати дослідження та їх обговорення. В результаті виконання першого кроку першого етаny дослідження (див. табл. 1) встановлено, що серед 262 осіб жіночої статі до цього моменту залишилися живими 241 хвора $(92,98$ \%), 21 жінка померла $(8,02 \%)$. Серед 32 чоловіків живими сьогодні є 24 (75,00\%), а померли - вісім (25,00\%). Такі результати вказують на те, що чоловіки з СЧВ достовірно $(\chi 2=7,52, \mathrm{p}<0,05)$ частіше помирають у порівнянні з жінками, хворими на СЧВ.

Нами обчислено (див. табл. 1), що вік 42 роки і 6 місяців є тим показником, який визначає ризик померти хворого на СЧВ. У нашій вибірці було 168 пацієнтів з СЧВ молодших за 42 роки i 6 місяців, 3-поміж яких живими досі залишилося 142 хворих $(81,69 \%) .3$ них померло 26 пацієнтів (18,31\%). Хворих, старших за 42 роки і 6 місяців було 125, 3 них живими на цей момент є 123 хворих (98,40\%), а померли - двоє (1,60\%). Хворі на СЧВ, що старші за 42,5 роки помирають достовірно рідше, ніж хворі на СЧВ, молодші вказаного віку $(\chi 2=14,85, \mathrm{p}<0,05)$.

Таблиця 1. Вплив статі та віку хворих на системний червоний вовчак на їх виживання $(\mathrm{n} ; \% ; \chi 2 ; \mathrm{p})$

\begin{tabular}{|c|c|c|c|c|c|c|c|c|c|}
\hline \multirow[t]{2}{*}{$\begin{array}{c}\text { № } \\
\text { за/п }\end{array}$} & \multirow{2}{*}{\multicolumn{2}{|c|}{ Чинник }} & \multirow[t]{2}{*}{$\begin{array}{c}\text { Хворі на } \\
\text { СЧВ } \\
\text { (всього) } \\
\\
\mathrm{n} \\
\end{array}$} & \multicolumn{2}{|c|}{$\begin{array}{c}\text { Хворі на СЧВ, } \\
\text { що померли }\end{array}$} & \multicolumn{2}{|c|}{$\begin{array}{c}\text { Хворі на СЧВ, } \\
\text { що живі }\end{array}$} & \multicolumn{2}{|c|}{$\begin{array}{c}\text { Результати } \\
\text { лог-ранк } \\
\text { тесту } \\
\text { Н. Мантела - } \\
\text { Д. Кокса }\end{array}$} \\
\hline & & & & $\mathrm{n}$ & $\%$ & $\mathrm{n}$ & $\%$ & $\chi^{2}$ & $p$ \\
\hline \multirow[t]{2}{*}{1} & \multirow[t]{2}{*}{ Стать } & Жінки & 262 & 21 & 8,02 & 241 & 91,98 & \multirow[t]{2}{*}{7,52} & \multirow[t]{2}{*}{0,01} \\
\hline & & Чоловіки & 32 & 8 & 25,00 & 24 & 75,00 & & \\
\hline \multirow[t]{2}{*}{2} & \multirow{2}{*}{$\begin{array}{l}\text { Вік на момент } \\
\text { обстеження }\end{array}$} & $\leq 42,5$ років & 168 & 26 & 18,31 & 142 & 81,69 & \multirow[t]{2}{*}{14,85} & \multirow[t]{2}{*}{0,00} \\
\hline & & $>42,5$ років & 125 & 2 & 1,60 & 123 & 98,40 & & \\
\hline
\end{tabular}

Отже, такі показники як стать та вік хворих на СЧВ впливають на можливість померти, а саме хворі чоловічої статі та у віці молодше 42,5 роки достовірно частіше помирають, ніж жінки та старші 42,5 років.

Наступний, другий крок цього етапу дослідження, який передбачав вивчення впливу на ризик смерті хворих на СЧВ наявності у них критеріїв ACR, дозволив встановити, що (див. табл. 2) ризик смерті хворих на СЧВ не збільшує: наявність у них симптому «метелика» на обличчі $(\chi 2=0,40, \mathrm{p}>0,05)$, дискоїдних висипань $(\chi 2=3,15, \mathrm{p}>0,05)$, фотосенсибілізації $(\chi 2=1,54$, $\mathrm{p}>0,05)$, виразок на слизовій оболонці ротової порожнини $(\chi 2=0,27, \mathrm{p}>0,05)$, артриту $(\chi 2=2,02$, $\mathrm{p}>0,05)$, перикардиту $(\chi 2=2,57, \mathrm{p}>0,05)$, чи плевриту $(\chi 2=1,50, \mathrm{p}>0,05)$. 
Таблиця 2. Вплив наявності критеріїв Американського коледжу ревматології у хворих на системний червоний вовчак на їх виживання $(\mathrm{n} ; \% ; \chi 2 ; \mathrm{p})$

\begin{tabular}{|c|c|c|c|c|c|c|c|c|c|}
\hline \multirow[t]{2}{*}{$\begin{array}{c}\text { № } \\
\text { 3a/ח }\end{array}$} & \multirow{2}{*}{\multicolumn{2}{|c|}{ Чинник }} & \multirow[t]{2}{*}{$\begin{array}{c}\text { Хворі на } \\
\text { СЧВ } \\
\text { (всього) } \\
\\
\mathrm{n}\end{array}$} & \multicolumn{2}{|c|}{$\begin{array}{l}\text { Хворі на } \\
\text { СЧВ, що } \\
\text { померли }\end{array}$} & \multicolumn{2}{|c|}{$\begin{array}{c}\text { Хворі на СЧВ, } \\
\text { що живі }\end{array}$} & \multicolumn{2}{|c|}{$\begin{array}{c}\text { Результати } \\
\text { лог-ранк } \\
\text { тесту } \\
\text { Н. Мантела - } \\
\text { Д. Кокса }\end{array}$} \\
\hline & & & & $\mathrm{n}$ & $\%$ & $\mathrm{n}$ & $\%$ & $x^{2}$ & $\mathrm{p}$ \\
\hline \multirow{2}{*}{1} & \multirow{2}{*}{ Симптом «метелика» } & $\epsilon$ & 162 & 16 & 9,88 & 146 & 90,12 & \multirow{2}{*}{0,40} & \multirow{2}{*}{0,53} \\
\hline & & Немає & 132 & 13 & 9,85 & 119 & 90,15 & & \\
\hline \multirow{2}{*}{2} & \multirow{2}{*}{ Дискоїдний висип } & $\epsilon$ & 26 & 0 & 0,00 & 26 & 100,00 & \multirow{2}{*}{3,15} & \multirow{2}{*}{0,08} \\
\hline & & Немає & 268 & 29 & 10,82 & 239 & 89,18 & & \\
\hline \multirow{2}{*}{3} & \multirow{2}{*}{ Фотосенсибілізація } & $\epsilon$ & 102 & 12 & 11,76 & 90 & 88,24 & \multirow{2}{*}{1,54} & \multirow{2}{*}{0,21} \\
\hline & & Немає & 192 & 17 & 8,85 & 175 & 91,15 & & \\
\hline \multirow{2}{*}{4} & \multirow{2}{*}{$\begin{array}{c}\text { Виразки слизової оболонки } \\
\text { ротової порожнини }\end{array}$} & $\epsilon$ & 64 & 6 & 9,38 & 58 & 90,63 & \multirow{2}{*}{0,27} & \multirow{2}{*}{0,61} \\
\hline & & Немає & 226 & 23 & 10,18 & 203 & 89,82 & & \\
\hline \multirow{2}{*}{5} & & $\epsilon$ & 64 & 3 & 4,69 & 61 & 95,31 & & \\
\hline & Артрит & Немає & 230 & 26 & 11,30 & 204 & 88,70 & 2,02 & 0,16 \\
\hline 6 & Сепозит (перикаплит) & $\epsilon$ & 51 & 9 & 17,65 & 42 & 82,35 & 257 & 011 \\
\hline 0 & Серозит (перикардит) & Немає & 243 & 20 & 8,23 & 223 & 91,77 & $2,5 /$ & 0,11 \\
\hline 7 & Сапорит (пгеопит) & $\epsilon$ & 39 & 2 & 5,13 & 37 & 94,87 & 150 & 022 \\
\hline 1 & Серозит (плеврит) & Немає & 255 & 27 & 10,59 & 228 & 89,41 & 1,50 & 0,22 \\
\hline & Ураження нирок & $\epsilon$ & 142 & 22 & 15,49 & 120 & 84,51 & 700 & 001 \\
\hline 8 & (протеїнурія) & Немає & 152 & 7 & 4,61 & 145 & 95,39 & 1,00 & 0,01 \\
\hline & Ураження нирок & $\epsilon$ & 32 & 6 & 18,75 & 26 & 81,25 & 713 & \\
\hline 9 & (циліндрурія) & Немає & 262 & 23 & 8,78 & 239 & 91,22 & 1,13 & 0,01 \\
\hline 10 & Ураження нервової системи & $\epsilon$ & 2 & 2 & 100,00 & 0 & 0,00 & 7017 & 000 \\
\hline 10 & (судоми) & Немає & 292 & 27 & 9,25 & 265 & 90,75 & $10,1 /$ & 0,00 \\
\hline & Ураження нервової системи & $\epsilon$ & 20 & 3 & 15,00 & 17 & 85,00 & & \\
\hline 11 & (психоз) & Немає & 274 & 26 & 9,49 & 248 & 90,51 & 0,20 & 0,61 \\
\hline 12 & Гематологічні порушення & $\epsilon$ & 7 & 1 & 14,29 & 6 & 85,71 & 024 & $0.56>>1$ \\
\hline 12 & ретикулоцитозом) & Немає & 287 & 28 & 9,76 & 259 & 90,24 & 0,34 & 0,50 \\
\hline 13 & Гематологічні порушення & $\epsilon$ & 45 & 7 & 15,56 & 38 & 84,44 & 137 & 024 \\
\hline 13 & (тромбоцитопенія) & Немає & 249 & 22 & 8,84 & 227 & 91,16 & 1,37 & 0,24 \\
\hline 14 & Гематологічні порушення & $\epsilon$ & 122 & 13 & 10,66 & 109 & 89,34 & 113 & 027 \\
\hline 14 & (лейкопенія & Немає & 172 & 16 & 9,30 & 156 & 90,70 & 1,13 & 0,21 \\
\hline 15 & Гематологічні порушення & $\epsilon$ & 19 & 5 & 26,32 & 14 & 73,68 & 1116 & 000 \\
\hline 15 & (лімфопенія) & Немає & 275 & 24 & 8,73 & 251 & 91,27 & 11,10 & 0,00 \\
\hline 16 & $\begin{array}{l}\text { Імунологічні порушення } \\
\text { (антитіла до двохспіральної }\end{array}$ & $\epsilon$ & 241 & 25 & 10,37 & 216 & 89,63 & 111 & 028 \\
\hline & $\begin{array}{c}\text { дезоксирибонуклеї-нової } \\
\text { кислоти) }\end{array}$ & Немас & 22 & 1 & 4,55 & 21 & 95,45 & & \\
\hline & Імунологічні порушення & $\epsilon$ & 37 & 5 & 13,51 & 32 & 86,49 & & \\
\hline 17 & $\begin{array}{l}\text { (антифосфолипцдн1 } \\
\text { імуноглобуліни М) }\end{array}$ & Немає & 88 & 3 & 3,41 & 85 & 96,59 & 3,11 & 0,08 \\
\hline 18 & Імунологічні порушення & E & 35 & 5 & 14,29 & 30 & 85,71 & 3.18 & 0.08 \\
\hline 10 & імуноглобуліни Джі) & Немає & 100 & 3 & 3,00 & 97 & 97,00 & 3,10 &, 00 \\
\hline 19 & Імунологічні порушення & $\epsilon$ & 2 & 1 & 50,00 & 1 & 50,00 & 10,68 & 0.00 \\
\hline 19 & (вовчаковий антикоагулянт) & Немає & 49 & 2 & 4,08 & 47 & 95,92 & & \\
\hline 20 & Антинуклеарні антитіла & $\epsilon$ & 214 & 15 & 7,01 & 199 & 92,99 & 111 & 020 \\
\hline & Антинуклеарні антитлла & Немає & 29 & 29 & 100,00 & 25 & 86,21 & 1,11 & 0,29 \\
\hline
\end{tabular}

Водночас виявлено, що хворі на СЧВ, у яких діагностовано протеїнурію, помирають достовірно частіше, ніж хворі, у яких такого відхилення немає $(\chi 2=7,00, \mathrm{p}<0,05)$. Ураження нирок у вигляді протеїнурії було у 142 хворих на СЧВ, з-поміж яких живими досі $є 120$ (84,51 \%), а померли -22 (15,49 \%). У 152 хворих протеїнурії не виявлено. 3-поміж них, 145 хворих досі є живими $(95,39$ $\%$ ), а семеро - померло (4,61 \%). Також, наявність циліндрурії у хворих на СЧВ достовірно підвищує ризик їх смерті $(\chi 2=7,13, \mathrm{p}<0,05)$. Циліндрурію виявлено у 32 хворих на СЧВ, з яких на цей момент живими залишилося 26 (81,25\%), а померло - шестеро (18,75\%). Із 262 хворих на СЧВ, у яких циліндрурії не було, до сьогодні живими є 239 (91,22 \%), а померли - 23 (8,78 \%). 
Нами підтверджено вплив ураження нервової системи (судоми) на ризик смерті хворих на СЧВ $(\chi 2=70,17, \mathrm{p}<0,05)$. Ураження нервової системи, а саме судоми зафіксовано у двох пацієнтів 3 СЧВ. Обоє цих хворих до цього моменту померли (100,00 \%). У 292 хворих на СЧВ судом не було. 3-поміж них $265 \epsilon$ досі живими (90,75 \%), а 27 - померло (9,25\%). Таке ураження нервової системи як психоз не впливає на зростання ризику хворому на СЧВ померти $(\chi 2=0,26, \mathrm{p}>0,05)$.

3-поміж гематологічних порушень ні гемолітична анемія 3 ретикулоцитозом, ні тромбоцитопенія, чи лейкопенія жодним чином не впливають на смертність хворих на СЧВ $(\chi 2=0,34, \mathrm{p}>0,05 ; \chi 2=1,37, \mathrm{p}>0,05 ; \chi 2=1,13, \mathrm{p}>0,05$, відповідно). Наявність у хворих на СЧВ лімфопенію достовірно збільшує ризик їх смерті $(\chi 2=11,16, p<0,05)$. Це гематологічне порушення виявлено у 19 хворих а СЧВ, з-поміж яких 14 досі живі (73,68 \%), а п'ятеро померло (26,32\%). Серед 275 хворих, у яких лімфопенію не виявлено, 251 хворий живий $(91,27$ $\%), 24$ - померло (8,73\%).

3-поміж імунологічних порушень впливу на смерть хворих не мало наявність антитіл до двохспіральної дезоксирибонуклеїнової кислоти $(\chi 2=1,11, \quad \mathrm{p}>0,05)$, антифосфоліпідних імуноглобулінів $\mathrm{M}(\chi 2=3,11, \mathrm{p}>0,05)$ та Джі $(\chi 2=3,18, \mathrm{p}>0,05)$, антинуклеарних антитіл $(\chi 2=1,11$, $\mathrm{p}>0,05)$, а наявність вовчакового антикоагулянту збільшувало ризик хворого на СЧВ померти $(\chi 2=10,68, \mathrm{p}<0,05)$. Серед двох хворих на СЧВ, у яких виявлено вовчаковий антикоагулянт, один залишився живий $(50,00 \%)$, а другий - помер (50,00 \%). Серед 49 хворих, у яких вказаного імунологічного порушення не виявлено, 47 досі живі (95,92 \%), а двоє - померло (4,08 \%).

Отже, ми маємо право стверджувати, що ризик померти хворому на СЧВ збільшується за умов наявності у нього судом, лімфопенію, вовчакового антикоагулянту і протеїн- та циліндрурії,. А такі критерії як симптом «метелика», дискоїдні висипання, фотосенсибілізація, виразки на слизовій оболонці ротової порожнини, артрит, перикардит, плеврит, психоз, деякі гематологічні (гемолітична анемія 3 ретикулоцитозом, тромбоцитопенія, лейкопенія) та імунологічні (наявність антитіл до двохспіральної дезоксирибонуклеїнової кислоти та антифосфоліпідні імуноглобуліни М та Джі, антинуклеарні антитіла) порушення не мають впливу на виживання хворих на СЧВ.

Результати вивчення впливу наявності патогенетично асоційованих з СЧВ уражень [2, 3] на виживання хворих, що є третім кроком цього етапу дослідження, наведено у таблиці 3

Таблиця 3. Вплив наявності патогенетично асоційованих із системним червоним вовчаком уражень на виживання хворих (n;\%; $\chi 2 ; \mathrm{p})$

\begin{tabular}{|c|c|c|c|c|c|c|c|c|c|}
\hline \multirow[t]{2}{*}{$\begin{array}{c}\text { № } \\
\text { 3a/ח }\end{array}$} & \multirow{2}{*}{\multicolumn{2}{|c|}{ Чинник }} & \multirow{2}{*}{$\begin{array}{c}\text { Хворі на } \\
\text { СЧВ } \\
\text { (всього) }\end{array}$} & \multicolumn{2}{|c|}{$\begin{array}{l}\text { Хворі на } \\
\text { СЧВ, що } \\
\text { померли }\end{array}$} & \multicolumn{2}{|c|}{$\begin{array}{c}\text { Хворі на СЧВ, } \\
\text { що живі }\end{array}$} & \multicolumn{2}{|c|}{$\begin{array}{c}\text { Результати } \\
\text { лог-ранк тесту } \\
\text { Н. Мантела - } \\
\text { Д. Кокса } \\
\end{array}$} \\
\hline & & & & $\mathrm{n}$ & $\%$ & $\mathrm{n}$ & $\%$ & $x^{2}$ & $\mathrm{p}$ \\
\hline 1 & 2 & 3 & 4 & 5 & 6 & 7 & 8 & 9 & 10 \\
\hline \multirow{2}{*}{1} & \multirow{2}{*}{$\begin{array}{c}\text { Aсептичний некроз } \\
\text { кісток }\end{array}$} & $\epsilon$ & 20 & 6 & 30,00 & 14 & 70,00 & \multirow{2}{*}{8,78} & \multirow{2}{*}{0,00} \\
\hline & & Немає & 274 & 23 & 8,39 & 251 & 91,61 & & \\
\hline \multirow{2}{*}{2} & \multirow{2}{*}{ Хронічний карієс } & $\epsilon$ & 49 & 10 & 20,41 & 39 & 79,59 & \multirow{2}{*}{7,97} & \multirow{2}{*}{0,01} \\
\hline & & Немає & 233 & 15 & 6,44 & 218 & 93,56 & & \\
\hline \multirow{2}{*}{3} & \multirow{2}{*}{ Хронічний періодонтит } & $\epsilon$ & 44 & 7 & 15,91 & 37 & 84,09 & \multirow{2}{*}{2,63} & \multirow{2}{*}{0,11} \\
\hline & & Немає & 238 & 18 & 7,56 & 220 & 92,44 & & \\
\hline \multirow{2}{*}{4} & \multirow[t]{2}{*}{ Артральгії } & $\epsilon$ & 281 & 28 & 9,96 & 253 & 90,04 & \multirow{2}{*}{0,03} & \multirow{2}{*}{0,88} \\
\hline & & Немає & 13 & 1 & 7,69 & 12 & 92,31 & & \\
\hline \multirow{2}{*}{5} & \multirow{2}{*}{ Міальгії } & $\epsilon$ & 104 & 7 & 6,73 & 97 & 93,27 & \multirow{2}{*}{1,58} & \multirow{2}{*}{0,21} \\
\hline & & Немає & 190 & 22 & 11,58 & 168 & 88,42 & & \\
\hline \multirow{2}{*}{6} & \multirow{2}{*}{ Остеопенія } & $\epsilon$ & 136 & 7 & 5,15 & 129 & 94,85 & \multirow{2}{*}{3,40} & \multirow{2}{*}{0,07} \\
\hline & & Немає & 77 & 8 & 10,39 & 69 & 89,61 & & \\
\hline 7 & Остеопороз & $\epsilon$ & 44 & 4 & 9,09 & 40 & 90,91 & 0,18 & 0,67 \\
\hline \multirow{2}{*}{8} & \multirow{2}{*}{ Геморагійний васкуліт } & $\epsilon$ & 8 & 1 & 12,50 & 7 & 87,50 & & \\
\hline & & Немає & 286 & 28 & 9,79 & 258 & 90,21 & 0,05 & 0,82 \\
\hline 9 & & $\epsilon$ & 9 & 1 & 11,11 & 8 & 88,89 & & 070 \\
\hline 9 & Капілярит & Немає & 285 & 28 & 9,82 & 257 & 90,18 & 0,15 & $0, / 0$ \\
\hline & & $\epsilon$ & 177 & 10 & 5,65 & 167 & 94,35 & & \\
\hline 10 & Синдром А. 1. М. Реино & Немає & 117 & 19 & 16,24 & 98 & 83,76 & 8,82 & 0,00 \\
\hline 11 & Атепоскпепоз & $\epsilon$ & 46 & 0 & 0,00 & 46 & 100,00 & 078 & 038 \\
\hline 11 & Атеросклероз & Немає & 27 & 2 & 7,41 & 25 & 92,59 & $0, / 8$ & 0,00 \\
\hline
\end{tabular}


Продовження таблиці 3

\begin{tabular}{|c|c|c|c|c|c|c|c|c|c|}
\hline 1 & 2 & 3 & 4 & 5 & 6 & 7 & 8 & 9 & 10 \\
\hline \multirow{2}{*}{12} & \multirow{2}{*}{ Ангіопатія сітківки } & $E$ & 113 & 19 & 16,81 & 162 & 143,36 & \multirow{2}{*}{0,30} & \multirow{2}{*}{0,58} \\
\hline & & Немає & 181 & 10 & 5,52 & 103 & 56,91 & & \\
\hline \multirow{2}{*}{13} & \multirow{2}{*}{ Ретикулярне ліведо } & $\epsilon$ & 77 & 10 & 12,99 & 67 & 87,01 & \multirow{2}{*}{0,24} & \multirow{2}{*}{0,62} \\
\hline & & Немає & 217 & 19 & 8,76 & 198 & 91,24 & & \\
\hline \multirow{2}{*}{14} & \multirow{2}{*}{ Тромбоз вен } & $\epsilon$ & 22 & 3 & 13,64 & 19 & 86,36 & \multirow{2}{*}{0,00} & \multirow{2}{*}{0,98} \\
\hline & & Немає & 272 & 26 & 9,56 & 246 & 90,44 & & \\
\hline \multirow{2}{*}{15} & \multirow{2}{*}{ Міокардит } & $\epsilon$ & 96 & 18 & 18,75 & 78 & 81,25 & 1036 & 000 \\
\hline & & Немає & 198 & 11 & 5,56 & 187 & 94,44 & 10,30 & 0,00 \\
\hline & Симптоматична & $\epsilon$ & 99 & 13 & 13,13 & 86 & 86,87 & & \\
\hline 10 & артеріальна гіпертензія & Немає & 195 & 16 & 8,21 & 179 & 91,79 & 0,04 & 0,43 \\
\hline & & $\epsilon$ & 53 & 6 & 11,32 & 47 & 88,68 & & \\
\hline 17 & Легенева г1пертенз1я & Немає & 190 & 13 & 6,84 & 177 & 93,16 & 1,20 & 0,27 \\
\hline & Ішемічна хвороба серця: & $\epsilon$ & 4 & 0 & 0,00 & 4 & 100,00 & & \\
\hline 18 & стабільна стенокардія & Немає & 170 & 11 & 6,47 & 159 & 93,53 & 0,91 & 0,32 \\
\hline & & $\epsilon$ & 57 & 11 & 19,30 & 46 & 80,70 & & \\
\hline 19 & Пневмоніт & Немає & 234 & 16 & 6,84 & 218 & 93,16 & 5,75 & 0,02 \\
\hline & & $\epsilon$ & 32 & 2 & 6,25 & 30 & 93,75 & & \\
\hline 20 & 11невмоф1ороз & Немає & 256 & 24 & 9,38 & 232 & 90,63 & 0,40 & 0,50 \\
\hline 21 & Пиерместперов & $\epsilon$ & 157 & 12 & 7,64 & 145 & 92,36 & 0.07 & 033 \\
\hline 21 & ППНЕВМОСКЛЕРОз & Немає & 131 & 14 & 10,69 & 117 & 89,31 & 0,91 & 0,53 \\
\hline & & $\epsilon$ & 26 & 8 & 30,77 & 18 & 69,23 & & \\
\hline 22 & Авто1муннии гепатит & Немає & 268 & 21 & 7,84 & 247 & 92,16 & 5,93 & 0,02 \\
\hline 23 & Стеатогепатит & $\epsilon$ & 44 & 5 & 11,36 & 39 & 88,64 & 0.07 & 070 \\
\hline 23 & СТеатогеПатит & Немає & 250 & 24 & 9,60 & 226 & 90,40 & 0,01 & 0,19 \\
\hline & & $\epsilon$ & 56 & 2 & 3,57 & 54 & 96,43 & & \\
\hline 24 & хрон1чнии панкреатит & Немає & 238 & 27 & 11,34 & 211 & 88,66 & 2,19 & 0,14 \\
\hline & & $\epsilon$ & 30 & 1 & 3,33 & 29 & 96,67 & & \\
\hline 25 & Авто1мунний тироідит & Немає & 260 & 28 & 10,77 & 232 & 89,23 & 2,40 & 0,12 \\
\hline 26 & Oxuniuse & $\epsilon$ & 53 & 7 & 13,21 & 46 & 86,79 & 120 & 027 \\
\hline 20 & Ожир1ння & Немає & 188 & 11 & 5,85 & 177 & 94,15 & 1,20 & 0,21 \\
\hline 27 & Органічний мозковий & $\epsilon$ & 17 & 2 & 11,76 & 15 & 88,24 & & \\
\hline 21 & синдром & Немає & 277 & 27 & 9,75 & 250 & 90,25 & 0,01 & 0,91 \\
\hline 28 & Дисциркуляторна & $\epsilon$ & 29 & 3 & 10,34 & 26 & 89,66 & 002 & 088 \\
\hline 28 & енцефалопатія & Немає & 265 & 26 & 9,81 & 239 & 90,19 & 0,02 & 0,80 \\
\hline 20 & & $\epsilon$ & 21 & 0 & 0,00 & 21 & 100,00 & 3.28 & \\
\hline 29 & Цефальгія & Немає & 273 & 29 & 10,62 & 244 & 89,38 & 3,28 & $0,0 /$ \\
\hline 30 & Вегето-сулинна пистонія & $\epsilon$ & 6 & 0 & 0,00 & 6 & 100,00 & 047 & 040 \\
\hline 30 & вегето-судинна дистонія & Немає & 288 & 29 & 10,07 & 259 & 89,93 & $0,4 /$ & 0,49 \\
\hline 31 & & $\epsilon$ & 89 & 11 & 12,36 & 78 & 87,64 & & \\
\hline 31 & Синдром «сухого ока» & Немає & 193 & 14 & 7,25 & 179 & 92,75 & 1,כ/ & 0,21 \\
\hline 32 & Vвё̈т & $\epsilon$ & 3 & 1 & 33,33 & 2 & 66,67 & 206 & \\
\hline 32 & У ве1т & Немає & 279 & 24 & 8,60 & 255 & 91,40 & 2,06 & 0,15 \\
\hline & & $\epsilon$ & 46 & 5 & 10,87 & 41 & 89,13 & & \\
\hline 33 & Катаракта & Немає & 236 & 20 & 8,47 & 216 & 91,53 & 0,11 & 0,14 \\
\hline 34 & Хпоніншй иен' & $\epsilon$ & 5 & 0 & 0,00 & 5 & 100,00 & 0.07 & 033 \\
\hline 34 & Хрон1чнии кон юктивІт & Немає & 277 & 25 & 9,03 & 252 & 90,97 & 0,91 & 0,35 \\
\hline & Ураження зорового & $\epsilon$ & 9 & 0 & 0,00 & 9 & 100,00 & & \\
\hline 35 & нерва & Немає & 285 & 29 & 10,18 & 256 & 89,82 & 0,72 & 0,40 \\
\hline & & $\epsilon$ & 5 & 0 & 0,00 & 5 & 100,00 & & \\
\hline 36 & Г лаукома & Немає & 277 & 25 & 9,03 & 252 & 90,97 & 0,67 & 0,41 \\
\hline & & $\mathrm{C}$ & 157 & 18 & 11,46 & 139 & 88,54 & & \\
\hline 37 & Анем1я & Немає & 137 & 11 & 8,03 & 126 & 91,97 & 1,904 & 0,17 \\
\hline 38 & Порушення оваріально- & $\epsilon$ & 27 & 3 & 11,11 & 24 & 88,89 & & 000 \\
\hline 38 & менструального циклу & Немає & 187 & 17 & 9,09 & 170 & 90,91 & 0,02 & 0,90 \\
\hline & & $\epsilon$ & 67 & 7 & 10,45 & 60 & 89,55 & & \\
\hline 39 & Набута дисл1п1дем1я & Немає & 222 & 21 & 9,46 & 201 & 90,54 & 0,32 & 0,57 \\
\hline 40 & & $\epsilon$ & 132 & 13 & 9,85 & 119 & 90,15 & & 0.68 \\
\hline 40 & Хрон1чнии тонзил1т & Немає & 156 & 13 & 8,33 & 143 & 91,67 & 0,18 & 0,08 \\
\hline & & $\epsilon$ & 80 & 4 & 5,00 & 76 & 95,00 & & \\
\hline 41 & Алопец1я & Немає & 214 & 25 & 11,68 & 189 & 88,32 & 2,11 & 0,15 \\
\hline
\end{tabular}


Отримані нами результати вказують на те, що лише наявність асептичного некрозу кістки та хронічного карієсу достовірно підвищує ризик смерті хворих на СЧВ $(\chi 2=8,78, \mathrm{p}<0,05$; $\chi 2=7,97, \mathrm{p}<0,05$, відповідно). На цей момент живими $є 14$ хворих $(70,00 \%)$ з СЧВ та асептичним некрозом кістки 3 20, що мали таке ураження. Шість пацієнтів з СЧВ та асептичним некрозом кістки померли $(30,00 \%)$. Серед 274 хворих на СЧВ без цього ураження живими є 251 (91,61\%), померли - 23 (8,39\%). Серед 49 хворих на СЧВ, що також мали діагностовано хронічний карієс, сьогодні є живими 39 (79,59\%), померло - десять $(20,41 \%)$. 218 хворих з СЧВ без хронічного карієсу є живими (93,56 \%), 15 - померло (6,44 \%) 3-поміж 233 хворих. Інші патогенетично асоційовані ураження кістково-м'язової системи не впливали на виживання хворих на СЧВ: хронічний періодонтит $(\chi 2=2,63, \mathrm{p}>0,05)$, артральгії $(\chi 2=0,03$, $\mathrm{p}>0,05)$, міальгії $(\chi 2=1,58, \mathrm{p}>0,05)$, остеопенія $(\chi 2=3,40, \mathrm{p}>0,05)$ та остеопороз $(\chi 2=0,18, \mathrm{p}>0,05)$.

Згідно отриманої нами інформації, жодне з уражень судин не збільшує ризику смерті хворих на СЧВ: геморагійний васкуліт $(\chi 2=0,05, \mathrm{p}>0,05)$, капілярит $(\chi 2=0,15, \mathrm{p}>0,05)$, синдром А. Г. М. Рейно $(\chi 2=8,82, \mathrm{p}>0,05)$, атеросклероз $(\chi 2=0,78, \mathrm{p}>0,05)$, ангіопатія сітківки $(\chi 2=0,30$, $\mathrm{p}>0,05)$, ретикулярне ліведо $(\chi 2=0,24, \mathrm{p}>0,05)$ та тромбоз вен $(\chi 2=0,00, \mathrm{p}>0,05)$.

3-поміж патогенетично асоційованих з СЧВ уражень системи кровообігу тільки наявність міокардиту достовірно впливало на смертність хворих $(\chi 2=10,36, p<0,05)$. Серед 96 хворих з СЧВ та міокардитом до сьогодні живими є 78 (81,25\%), а померли - 18 (18,75 \%). А серед 198 хворих на СЧВ без міокардиту на цей момент живими ж 187 (94,44 \%), а померли одинадцять $(5,56 \%)$. Інші ураження системи кровообігу не впливали на виживання хворих на СЧВ: симптоматична артеріальна гіпертензія $(\chi 2=0,64, \mathrm{p}>0,05)$, легенева гіпертензія $(\chi 2=1,20$, $\mathrm{p}>0,05)$ та стабільна стенокардія $(\chi 2=0,97, \mathrm{p}>0,05)$.

Серед патогенетично асоційованих уражень дихальної системи тільки пневмоніт достовірно сприяв зростанню смертності хворих на СЧВ $(\chi 2=5,75, \mathrm{p}<0,05) .357$ хворих на СЧВ та пневмоніт живими є 46 (80,70\%), а померли - одинадцять (19,30\%). А з 234 хворих на СЧВ без пневмоніту досі живі 218 (93,16\%), померли - 16 (6,84\%). Ні пневмофіброз, ні пневмосклероз не впливають на зростання смертності хворих на СЧВ $(\chi 2=0,46, p>0,05 ; \chi 2=0,97$, p>0,05 відповідно).

Серед патогенетично асоційованих із СЧВ уражень органів травлення лише автоімунний гепатит сприяв зростанню смертності хворих $(\chi 2=5,93, p<0,05)$. 3-поміж 26 хворих, які мали це ураження органів травлення на цей момент живими є 18 (69,23\%), а померли - восьмеро (30,77\%). А з 268 хворих на СЧВ без автоімунного гепатиту 247 живі $(92,16 \%)$, а 21 - помер $(7,84 \%)$. Стеатогепатит та хронічний панкреатит не мають зв'язку зі зростанням смертності хворих на СЧВ ( $\chi 2=0,07, \mathrm{p}>0,05 ; \chi 2=2,19 \mathrm{p}>0,05$ відповідно).

Інші патогенетично асоційовані із СЧВ ураження інших органів не мали зв'язку із смертністю хворих на СЧВ, а саме: автоімунний тироїдит $(\chi 2=2,40, p>0,05)$, ожиріння $(\chi 2=1,20$, $\mathrm{p}>0,05)$, органічний мозковий синдром $(\chi 2=0,01, \mathrm{p}>0,05)$, дисциркуляторна енцефалопатія $(\chi 2=0,02$, $\mathrm{p}>0,05)$, цефальгія $(\chi 2=3,28, \mathrm{p}>0,05)$, вегето-судинна дистонія $(\chi 2=0,47, \mathrm{p}>0,05)$, синдром «сухого ока» $(\chi 2=1,57, \mathrm{p}>0,05)$, увеїт ( $\chi 2=2,06, \mathrm{p}>0,05)$, катаракта $(\chi 2=0,11, \mathrm{p}>0,05)$, хронічний кон'юктивіт $(\chi 2=0,97, \mathrm{p}>0,05)$, ураження зорового нерва $(\chi 2=0,72, \mathrm{p}>0,05)$, глаукома $(\chi 2=0,67, \mathrm{p}>0,05)$, анемія $(\chi 2=1,90, \mathrm{p}>0,05)$, порушення оваріально-менструального циклу $(\chi 2=0,02, \mathrm{p}>0,05)$, набута дисліпідемія $(\chi 2=0,32, \mathrm{p}>0,05)$, хронічний тонзиліт $(\chi 2=0,18, \mathrm{p}>0,05)$ та алопеція $(\chi 2=2,11, \mathrm{p}>0,05)$.

Виконавши третій крок першого етапу дослідження, можемо стверджувати, шо у хворих на СЧВ ризик смерті збільшують наявність міокардиту, пневмоніту, автоімунного гепатиту, асептичного некрозу кісток та хронічного карієсу. Інші патогенетично асоційовані 3 СЧВ ураження (геморагійний васкуліт, капілярит, синдром А. Г. М. Рейно, атеросклероз, ангіопатія сітківки, ретикулярне ліведо, тромбоз вен, симптоматична артеріальна гіпертензія, легенева гіпертензія, стабільна стенокардія, пневмофіброз, пневмосклероз, стеатогепатит, хронічний панкреатит, хронічний періодонтит, артральгії, міальгії, остеопенія, остеопороз, порушення оваріально-менструального циклу, органічний мозковий синдром, дисциркуляторна енцефалопатія, цефальгія, вегето-судинна дистонія, анемія, автоімунний тироїдит, ожиріння, хронічний тонзиліт, набута дисліпідемія, синдром «сухого ока», увеїт, катаракта, хронічний кон'юктивіт, ураження зорового нерва, глаукома, алопеція) на ризик смерті не впливають.

Отже, ризик померти є вище хворим на з СЧВ чоловікам, молодшим 42,5 років із протеїн- та циліндрурією, судомами, лімфопенією та вовчаковим антикоагулянтом, а також із 
наявністю міокардиту, пневмоніту, автоімунного гепатиту, асептичного некрозу кісток та хронічного карієсу.

Наступним, другим етапом цього дослідження є виокремлення констеляції чинників, які б найбільш вагомо впливали на ризик померти хворому на СЧВ.

Шляхом низки обрахунків ми виявили, що найбільш вагомо на ризик смерті хворого на СЧВ впливає чоловіча стать, маса - більше ніж 92,5 кг та наявність у хворого автоімунного гепатиту (див. рис. 1). 3-поміж 222 хворих, які цих ознак не мали, на цей момент живими є 212 $(95,50 \%)$, а померли - десять $(4,50 \%)$. Серед 72 хворих, які мали б хоча б одну таку ознаку, живими є $53(73,61 \%)$, а померли - $19(26,39 \%)$.

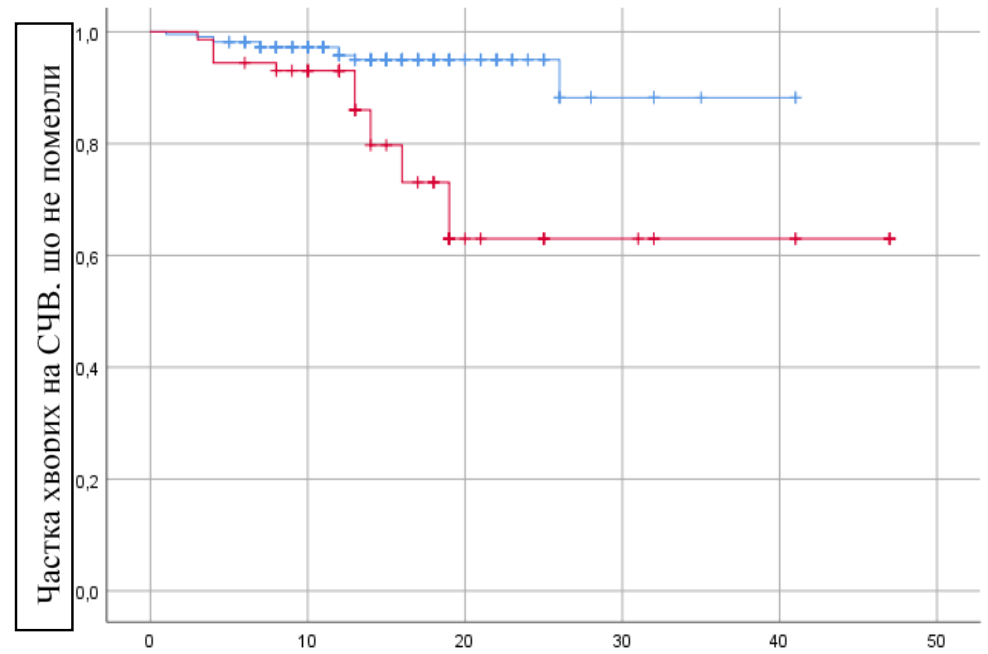

Кількість років від початку хвороби до сьогодні, роки

— - відсутність ознак, — - наявність хоча б одної з чотирьох ознак

Рис. 1. Крива виживання хворих на СЧВ

Отже, ризик смерті хворого на СЧВ найбільше збільшують чоловіча стать, маса тіла більше 92,5 кг та наявність автоімунного гепатиту.

Висновки. Чинниками, що збільшують смертність хворих на СЧВ, $є$ чоловіча стать, вік (молодші за 42,5 років), протеїн- та циліндрурія, судоми, лімфопенія, вовчаковий антикоагулянт, також наявність міокардиту, пневмоніту, автоімунного гепатиту, асептичного некрозу кісток та хронічного карієсу, проте найбільш вагомим є поєднання чоловічої статі, збільшеної маси тіла понад 92,5 кг та автоімунного гепатиту.

\section{ЛIТЕРАТУРА}

1. Абрагамович У., Абрагамович О., Циганик Л., Фармага М., Синенький В. Методика визначення функціонального класу хворого на системний червоний вовчак. World Science. 2020:5(57),Vol.2:10-19.

2. Abrahamovych U., Abrahamovych O., Svintsitsky A., Farmaha M., Guta S., Chemes V. Characteristics and Features of Spread of Pathogenetically Associated with the Systemic Lupus Erythematosus Lesions of Endocrine System. Experimental \& Clinical Medicine. 2020; 1:103-110.

3. Abrahamovych U.O., Abrahamovych O.O., Farmaha M.L., Romanyuk O.T., Kobak L.O. Pathogenetic Association of Vascular and Cardiac Lesions with Systemic Lupus Erythematosus: Charasteristics and Prevalence. Art of Medicine. 2020;2(14):6-15.

4. Aringer M., Schneider M. Systemischer Lupus erythematodes [Systemic lupus erythematosus]. Dtsch Med Wochenschr. 2016;141(8):537-543.

5. Fava A., Petri M. Systemic lupus erythematosus: Diagnosis and clinical management. J Autoimmun. 2019; 96:1-13.

6. Harzallah A., Kaaroud H., Hajji M., et al. Predictive factors of mortality in a tunisian cohort with systemic lupus erythematosus. Saudi J Kidney Dis Transpl. 2017;28(4):792-798.

7. Ocampo-Piraquive V., Nieto-Aristizábal I., Cañas C.A., Tobón G.J. Mortality in systemic lupus erythematosus: causes, predictors and interventions. Expert Rev Clin Immunol. 2018;14(12):1043-1053.

8. Tunnicliffe D.J., Singh-Grewal D., Kim S., Craig J.C., Tong A. Diagnosis, Monitoring, and Treatment of Systemic Lupus Erythematosus: A Systematic Review of Clinical Practice Guidelines. Arthritis Care Res (Hoboken). 2015;67(10):1440-1452. 